\title{
PEDAGÓGUSOK AZ INFORMÁCIÓS TECHNOLÓGIÁKRÓL ÉS AZ ALKALMAZOTT OKTATÁSI MÓDSZEREKRŐL
}

\author{
FARKAS ANDRÁS ${ }^{*}$ - FARKASNÉ GÁBRIEL MÓNIKA ${ }^{* *}$ \\ * a Nyugat-magyarországi Egyetem Savaria Egyetemi Központjának \\ adjunktusa \\ f_andras@ttmk.nyme.hu \\ ** történelem - ének-zene szakos tanár, \\ szakvizsgázott mentortanár \\ gabriel-monika@freemail.hu
}

A pedagóguskutatás paradigmaváltásainak történetében az 1980-as évektöl kezdödöen a pedagógus tudása, gondolkodása, meglévö nézeteinek tanulmányozása vált központi kérdéssé. Az ez irányú vizsgálódások céljai között legtöbbször a szakma, illetve a képzés megújitására való törekvés húzódott meg. A szerzök kutatása is a megújuláshoz kiván hozzájárulni, a digitális írástudásra, az alkalmazott oktatási módszerekre, s ezen belül, kiemelten a projektoktatás gyakorlati tapasztalataira vonatkozó tanitói és tanári vélekedések feltárásával.

\section{A kutatás szakmai céljairól}

Napjainkban a formálódó új pedagógusképzési és -továbbképzési rendszereknek nagymértékben támaszkodnia kell a közoktatási intézményekre, mint a gyakorlati képzés színtereire, továbbá a pedagógusokra, a tanárjelöltek és kezdő tanárok leendő mentoraira. Ezért nem érdektelen, hogy a tapasztalt pedagógusok szakmai, módszertani, továbbá informatika-pedagógiai felkészültsége milyen átadható tudást képvisel. Az elmúlt években felerősödtek azok a tendenciák a köz- és a felsőoktatásban, melyek a kompetenciaalapú tanulás- és tanításszervezés irányába hatottak. 2007-2008-ban már vizsgálhatónak látszott, hogy e tendenciák milyen változásokat hoztak a gyakorló pedagógusok körében az információs és kommunikációs technológiákhoz kapcsolódó kompetenciák területén.

A bemutatásra kerülő kutatás egyrészt az információs és kommunikációs technológiákhoz kapcsolódó viszonyulásokat vizsgálta pedagógusok körében. Kiindulópontunk az volt, hogy az informatika jelen van, jelen lehet különféle pedagógiai tevékenységekben (tanulási környezet kialakítása, tervezés, értékelés stb.), valamint, hogy a digitális kompetencia áthatja a Nemzeti Alaptanterv müveltségterületeit. E megközelítés fényében megállapítható, hogy érdemes információkat szerezni a pályán lévő pedagógusoktól arról, hogyan vélekednek az információs technológiák alkalmazásáról. Szembesülhetünk napjainkban azzal is, hogy erős igényként jelenik 
meg a tanulásra, a tanulóra koncentráló módszertani megújulás. Erre figyelve a kutatás másrészt arra irányult, hogy a pedagógusok miképpen viszonyulnak a tanulásszervezés, valamint az alkalmazott oktatási módszerek terén megjelenő elvárásokhoz. A módszerek közül kiemelt figyelmet szenteltünk a projektmódszernek ${ }^{1}$, amelynek az volt az oka, hogy az előző években több fejlesztő programban is hangsúlyos szerepet kapott a projektmódszer, illetve a kooperatív oktatás elterjesztése. Fontosnak tartottuk annak vizsgálatát is, hogy milyen forrásokból nyerik a pedagógusok a projektpedagógiára irányuló ismereteiket. Úgy véltük, hogy a kapott eredmények alapján következtetések fogalmazhatók meg az átalakuló pedagógusképzés és pedagógus-továbbképzések tartalmára és metodikájára vonatkozóan is.

\section{A kutatás módszerei, körülményei}

A kutatás kérdöives módszerrel történt. A kérdőív tartalmilag két nagy egységből állt, mely egyrészt a gyakorló általános iskolai pedagógusok informatikához füződő viszonyulásait, az oktatásban történő alkalmazásának szándékait vizsgálta, másrészt, ezzel összefüggésben az alkalmazott oktatási módszerekről és azok forrásairól kívánt információkat szerezni. A kérdőívben zárt és nyílt kérdésekkel éltünk. A kérdöívek kitöltése anonim módon, önkéntesen történt.

A vizsgálatba bevont intézmények kiválasztását elsősorban a válaszadói hajlandóság ,irányította”. A mintába három Vas megyei iskola (kettő nagyvárosi, egy kistelepülésen lévő), hat Zala megyei kistelepülés iskolája és egy Heves megyei kisiskola, illetve pedagógusai kerültek be. A 97 válaszoló pedagógus 31 százaléka dolgozik nagyvárosi (500 diák feletti) általános iskolában, 69 százaléka pedig kistelepüléseken müködő alacsonyabb létszámú intézményben.

A válaszolók közül 38 pedagógus csak alsó tagozatban tanít, 31 fö pedig 5-8. évfolyamban. A válaszadók közül öt fő jelezte, hogy az alsó tagozaton kívül tanít 5-6. évfolyamban is, továbbá 18 pedagógus nyilatkozott úgy, hogy az alsó, valamint a teljes felső tagozatban is tart órákat. Ez annak is köszönhető, hogy a 49 tanítói végzettségü közül 10 fő tanárszakkal is rendelkezik. A 97 megkérdezett pedagógus összesen 24-féle szakot végzett, melyek közül a tanító, továbbá a magyar, matematika és történelem szakok képviseltették magukat 10 föt meghaladó mértékben. A válaszadók közel fele, a tanító szakosok közül pedig több mint a fele 20 évnél régebben van a pályán (1. táblázat). Egy, a tanítói munka változásairól szóló 2007-es felmérés (Kerber, 2007) reprezentatív mintával dolgozott, eredményei azt mutatták, hogy a válaszadók 81,4 százaléka 15 évnél régebben van a pályán. A jelen felmérésben ez az érték 77,3 százalék.

\footnotetext{
${ }^{1}$ A szakirodalom sokféle fogalmat használ, többek között: projektmódszer, projektoktatás, pedagógiai projekt, projektpedagógia, projektorientált oktatás (M. Nádasi, 2003).
} 
1. táblázat: A válaszadók megoszlása a pályán eltöltött idő szerint

\begin{tabular}{|l|r|r|r|r|}
\hline & \multicolumn{2}{|c|}{ Összes válaszadó } & \multicolumn{2}{c|}{$\begin{array}{c}\text { Tanitó } \\
\text { szakosok }\end{array}$} \\
\hline $1-3$ év & 10 fö & $10,3 \%$ & 4 fö & $8,2 \%$ \\
\hline $4-5$ év & 6 fö & $6,2 \%$ & 3 fö & $6,1 \%$ \\
\hline $5-10$ év & 6 fö & $6,2 \%$ & 1 fö & $2,0 \%$ \\
\hline $10-15$ év & 11 fö & $11,3 \%$ & 7 fö & $14,3 \%$ \\
\hline $15-20$ év & 18 fö & $18,6 \%$ & 9 fö & $18,4 \%$ \\
\hline 20 évnél több & 46 fö & $47,4 \%$ & 25 fö & $51,0 \%$ \\
\hline összesen: & 97 fö & & 49 fö & \\
\hline
\end{tabular}

\section{A pedagógusok informatikai eszközhasználatával kapcsolatos eredmények}

\section{Állitások az IKT használatáról}

Az elmúlt években több kutatás zajlott az informatikai írástudásról. Körösné Mikis Márta például azt vizsgálta, hogy az információs technológiákra épülő kompetenciafejlesztésnek milyen akadályai vannak, különösen az oktatás kezdő, alapozó szakaszában (Körösné, 2006). Átfogó informatikai felmérés zajlott 2006-ban az informatika területén már tapasztalatot szerzett pedagógusok körében (Hunya, 2008). A következö problémák vizsgálatára került sor: Miképp ösztönzi az iskolavezetés a számítógépek tanórai alkalmazását? Hogyan viszonyulnak a pedagógusok az IKT eszközökhöz, az SDT-hez? A kutatások eredményeiből kiemelkedett egy, vizsgálatra érdemes kérdéskör: A ma már nagyobb számban elérhető, e témára irányuló szakmai, informatika-pedagógiai szakirodalom, a rendelkezésre álló eszközök, valamint továbbképzések elég tudást és motivációt nyújtanak-e a számítógépek oktatási felhasználására?

A felmérésben elsőként arról gyüjtöttünk adatokat, hogy használnak-e számítógépet az oktatást előkészítő munkájukban és az oktatásban a pedagógusok. A lényeg az alkalmazáson volt, így nem kívántuk differenciálni a kérdést, hogy tanórán, az oktatási intézményben, illetve otthon; adminisztratív feladatokra vagy feladatlapok készítésére és nyomtatására, szakmai ismeretek bővítésére, szemléltetésre stb. használja-e a pedagógus a számítógépet. Az önbevallásra épülő kérdésre adott válaszok összesítését a 2. táblázat mutatja. 
2. táblázat: Használ-e számítógépet oktatási, oktatást előkészítő munkájában?

\begin{tabular}{|l|c|c|}
\hline naponta, illetve majdnem minden nap & 30 fö & $30,9 \%$ \\
\hline hetente 2-3 alkalommal & 22 fö & $22,7 \%$ \\
\hline hetente legalább egyszer & 13 fö & $13,4 \%$ \\
\hline havonta néhányszor & 15 fö & $15,5 \%$ \\
\hline ritkábban & 12 fö & $12,4 \%$ \\
\hline nem használok, mert & & \\
\hline nem megfelelöek az informatikai ismereteim; & 3 fö & $3,1 \%$ \\
\hline ismereteim vannak, a szándék hiányzik. & 2 fö & $2,1 \%$ \\
\hline
\end{tabular}

Az eredmény tükrözi a korábban idézett felmérésekben tapasztaltakat. Az adatok alapján megállapítható, hogy a vidéki, kistelepülésen dolgozók esetében a hetente oktatási célból számítógép elé ülő pedagógusok aránya 10 százalékkal magasabb a városi iskolákban dolgozókhoz képest, illetve a tanító szakos pedagógusoknál ez az érték 6 százalékkal alacsonyabb, mint a teljes minta (67\%) esetében (3. táblázat).

3. táblázat: Használ-e számítógépet oktatási, oktatást előkészítő munkájában (részletezve)?

\begin{tabular}{|l|c|c|c|}
\hline & $\begin{array}{c}\text { tanító szakos } \\
\text { pedagógusok }\end{array}$ & $\begin{array}{c}\text { nagyvárosi } \\
\text { iskolában tanitók }\end{array}$ & $\begin{array}{c}\text { kistelepülésen } \\
\text { dolgozók }\end{array}$ \\
\cline { 2 - 4 } $\begin{array}{l}\text { naponta, illetve majdnem minden } \\
\text { nap }\end{array}$ & $26,5 \%$ & $30,0 \%$ & $31,3 \%$ \\
\hline hetente 2-3 alkalommal & $18,4 \%$ & $20,0 \%$ & $23,9 \%$ \\
\hline hetente legalább egyszer & $16,3 \%$ & $10,0 \%$ & $14,9 \%$ \\
\hline $\begin{array}{l}\text { hetente számítógépet használók } \\
\text { aránya: }\end{array}$ & $\mathbf{6 1 , 2 \%}$ & $\mathbf{6 0 , 0 \%}$ & $\mathbf{7 0 , 1 \%}$ \\
\hline havonta néhányszor & $14,3 \%$ & $20,0 \%$ & $13,4 \%$ \\
\hline ritkábban & $20,4 \%$ & $13,3 \%$ & $11,9 \%$ \\
\hline nem használok & $4,1 \%$ & $3,3 \%$ & $3,0 \%$ \\
\hline $\begin{array}{l}\text { nem megfelelöek az informatikai } \\
\text { ismereteim; }\end{array}$ & $0 \%$ & $3,3 \%$ & $1,5 \%$ \\
\hline $\begin{array}{l}\text { ismereteim vannak, a szándék } \\
\text { hiányzik. }\end{array}$ & & & \\
\hline
\end{tabular}




\section{A pedagógusok informatikai ismeretei}

Az oktatási felhasználás egyik alapfeltétele a megfelelő szakmai számítógépes tudás megléte. Ehhez kapcsolódóan a felmérés azzal foglalkozott, hogy a gyakorló pedagógusok milyen mértékben rendelkeznek informatikai végzettségekkel, kiemelten ECDL, OKJ vizsgákkal, beleértve továbbá a felsőoktatásban elvégzett kurzusokat, valamint egyéb tanfolyami keretben történő ismeretszerzéseket is. Ezek a képzések nagyon eltérő színvonalat jelenthetnek, illetve eltérő (elsősorban nem pedagógiai) szakmai célokat fogalmaznak meg. Ugyanakkor például az ECDL és OKJ képzések esetében az akkreditált programok miatt tudható, hogy milyen szakmai ismereteket „kell” birtokolni azoknak, akik sikeresen teljesítették ezeket. Hunya Márta 2006-os felmérésében (Hunya, 2008) a válaszadók 30 százaléka végzett legalább 30 órás informatikai tanfolyamot. Vizsgálatunkban kapott eredmények sokkal magasabb értékeket mutatnak. (Lásd 4. táblázat.) Mindössze 24 százalék körül van azoknak a száma, akik semmiféle végzettséggel nem rendelkeznek, annak ellenére, hogy a válaszadók 47,4 százaléka 20 évnél régebben dolgozik a pályán.

4. táblázat: Rendelkezik-e számítástechnikai végzettséggel?

\begin{tabular}{|l|c|c|c|c|}
\hline & teljes minta & $\begin{array}{c}\text { tanitó szakos } \\
\text { pedagógusok }\end{array}$ & $\begin{array}{c}\text { nagyvárosi } \\
\text { iskolában } \\
\text { tanitók }\end{array}$ & $\begin{array}{c}\text { kistelepülésen } \\
\text { dolgozók }\end{array}$ \\
\hline Nem rendelkezik & $23,7 \%$ & $24,5 \%$ & $23,3 \%$ & $23,9 \%$ \\
\hline $\begin{array}{l}\text { ECDL vizsgát tett } \\
(4 \text { vagy 7 modul) }\end{array}$ & $23,7 \%$ & $28,6 \%$ & $30,0 \%$ & $20,9 \%$ \\
\hline $\begin{array}{l}\text { OKJ vizsgával } \\
\text { (alap és középfok) }\end{array}$ & $18,6 \%$ & $14,3 \%$ & $16,7 \%$ & $19,4 \%$ \\
\hline $\begin{array}{l}\text { Felsőfokú informatikai } \\
\text { végzettséggel }\end{array}$ & $10,3 \%$ & $8,2 \%$ & $3,3 \%$ & $13,4 \%$ \\
\hline $\begin{array}{l}\text { Bármilyen intézményi } \\
\text { szervezésben elvégzett } \\
\text { tanfolyami végzettséggel }\end{array}$ & $22,7 \%$ & $22,4 \%$ & $26,7 \%$ & $20,9 \%$ \\
\hline Egyéb & $1 \%$ & $2 \%$ & $0 \%$ & $1,5 \%$ \\
\hline Összesítve rendelkezik: & $76,3 \%$ & $75,5 \%$ & $76,7 \%$ & $76,1 \%$ \\
\hline $\begin{array}{l}\text { ECDL+OKJ vizsgát } \\
\text { tettek aránya: }\end{array}$ & $42,3 \%$ & $42,9 \%$ & $46,7 \%$ & $40,3 \%$ \\
\hline
\end{tabular}




\section{A számitógéphez füződö viszonyulások}

A felmérés következö informatikai témájú kérdése arra kérte a pedagógusokat, hogy minösitsék a számitógéphez füzödő viszonyulásaikat. Öt megállapítás közül kellett kiválasztaniuk a rájuk legjellemzőbbet. A kategóriák az alábbiak voltak:

1. Ha lehetséges, kikerülöm használatát.

2. Vannak olyan területek, ahol hasznosnak tartom, de nem foglalkoztat különösebben. Minimális tudásra törekszem. Esetleg tervezem ebben az irányban ismereteim bővítését.

3. Átlagos felhasználásra törekszem. Célom, hogy jó színvonalon legyek képes megoldani a feladataimat, de érdeklödési köröm teljesen más irányba mutat.

4. Egyre több területen tudom felhasználni a számítógépet, $s$ ahogy tudásom gyarapodik, egyre jobban kelti fel az érdeklődésemet. Kihívásnak tartom, $\mathrm{s}$ úgy gondolom, hogy az információs technológiák alapvetően meghatározzák életünket, így a munkámat is.

5. Lelkes híve vagyok az informatika - számítástechnika világának. Az elektronikus kommunikációs formák most is meghatározzák mindennapjaimat. Ahol csak lehetséges használom a számítógépeket, s fejlesztem tudásom a különféle alkalmazások területén.

A válaszok megoszlását az 1. ábra diagramja mutatja.

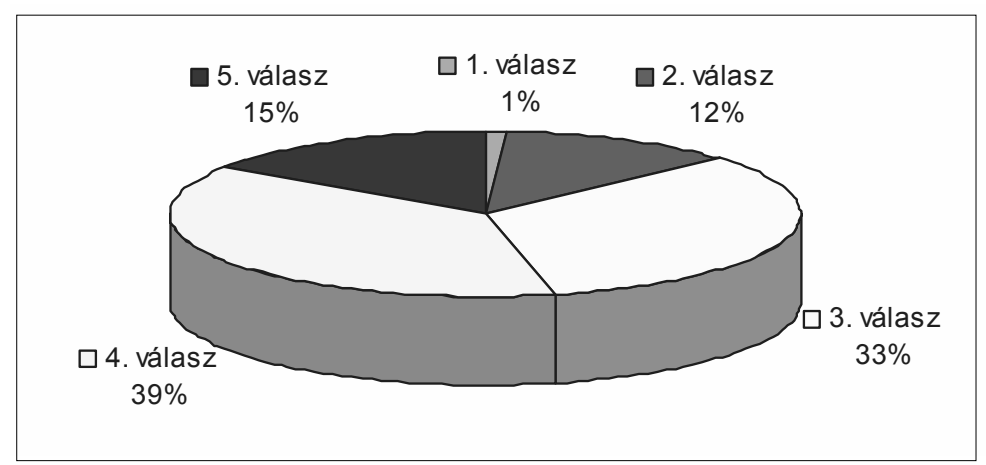

1. ábra: A számítógéphez füződő viszonyulások megoszlása

A teljes elutasítástól a lelkesen hívő véleményig terjedtek a válaszok, de csak egy pedagógus utasította el teljes mértékben, és 15,5 százalékuk tartotta magát lelkes elfogadónak. A negyedik és ötödik kategóriára adott válaszok összesítésével megállapítható, hogy a válaszadók 53,6 százaléka tartozik abba a körbe, akik feltételezhetően komoly elszántsággal fordulnak az IKT felé. Az első három válaszlehetősé- 
get megjelöltek (46,4\%) inkább minimális, illetve átlagos tudásra kívánnak szert tenni, céljuk, feltételezhetően lépést tartani a korral.

Tanulságos, s érthető összefüggés az is, hogy azoknak a pedagógusoknak, akik nem rendelkeznek semmiféle végzettséggel, 60,9 százaléka jelölte meg a második, illetve harmadik lehetőséget. Akik pedig például ECDL vizsgával rendelkeznek (de OKJ esetében is hasonló az eredmény), ugyanezeket a válaszlehetőségeket 30,4 százalékban választották. Másképp megfogalmazva az informatikai végzettséggel rendelkezők 58,1 százaléka jelölte be a negyedik, illetve az ötödik válaszlehetőséget. Úgy tünik tehát, hogy a szakmai hozzáértés, a magabiztosabb számitógép-kezelés kiindulópontja annak a folyamatnak, ahol a számitógép alkalmazását már a támogató attitüd és nem az elzárkózás jellemzi.

Egy további összefüggés, hogy az 1-5 éve pályán lévők 75 százaléka választotta a negyedik vagy ötödik válaszlehetőséget, ugyanez az 5-15 éve pályán lévők esetében már 47 százalék. 15 év felett ez az arány nem változik jelentősen, marad 50 százalék körül.

\section{A pedagógusok szándékai az oktatási célú felhasználással kapcsolatban}

Az előbbi gondolatkör inkább a számítástechnikához kapcsolódó egyéni, fogalmazhatnánk úgy, hogy személyes „kapcsolódást” kutatta, s a kérdőívben a pedagógusi szerephez kapcsolódóan is sor került a pedagógusok számítógéppel kapcsolatos szándékainak a vizsgálatára. A válaszolóknak négy lehetséges válaszlehetőség közül kellett a meggyőződésükhöz legjobban illö egyetlen egy megfogalmazást kiválasztani:

Gondolja végig, hogy jelenlegi elképzelései alapján milyen szerepet szán a számitógépek oktatásban történö felhasználásának.

1. Semmilyet, inkább óvnám a gyerekeket, tanítványaimat a számítógépektől.

2. Minimális időt szánnék rá, de elfogadva, hogy a gyerekek/tanítványok gyorsan tanulnak, és nagy az érdeklődésük e témakörben. A „szükséges rossz" kategóriája számomra.

3. Biztos vagyok abban, hogy szükség van informatikai ismeretek közvetítésére az adott korosztály számára. Mivel kihívásnak tartom, ha lehetőségem lenne rá, hangsúlyosan külön órát/foglalkozást szánnék erre. Ugyanakkor korlátoznám is a használatát, törekednék az általam helyesnek tartott arányok betartására. A hagyományos módszerek/foglalkozások híve vagyok, az informatika által nyújtott lehetőségeket nem meghatározónak, csak másodlagosnak tartom.

4. Úgy vélem, hogy az informatikának meghatározó helye van az általam gondozott korosztály esetében. Törekednék arra, hogy különféle felhasználási körökben, gyakorlatközelien, új módszereket felhasználva, több müveltségterületet is bevonva készítsem fel tanítványaimat az információs 
társadalom kihívásaira, s fejlesszem képességeiket. Nagy lehetőségeket látok az informatika oktatási felhasználásában, fejlesztve tudásom, ahol csak lehet alkalmazni szeretném.

Az eredményeket az 5. táblázat mutatja.

5. táblázat: Milyen szerepet szán a számítógépek oktatásban történő felhasználásának?

\begin{tabular}{|l|c|c|c|c|c|}
\hline $\begin{array}{c}\text { válaszok } \\
\text { kategóriái }\end{array}$ & $\begin{array}{c}\text { teljes } \\
\text { minta } \\
\text { (fö) }\end{array}$ & $\begin{array}{c}\text { teljes minta } \\
\text { (százalék) }\end{array}$ & $\begin{array}{c}\text { tanitó szakosok } \\
\text { válaszai } \\
\text { (százalék) }\end{array}$ & $\begin{array}{c}\text { nagyvárosi } \\
\text { iskolákban } \\
\text { tanitók } \\
\text { (százalék) }\end{array}$ & $\begin{array}{c}\text { vidéki } \\
\text { iskolákban } \\
\text { tanitók } \\
\text { (százalék) }\end{array}$ \\
\hline 1. & 0 fo & $0,0 \%$ & $0,0 \%$ & $0 \%$ & $0 \%$ \\
\hline 2. & 4 fó & $4,1 \%$ & $2,0 \%$ & $0 \%$ & $6,0 \%$ \\
\hline 3. & 60 fö & $61,9 \%$ & $65,3 \%$ & $53,3 \%$ & $65,7 \%$ \\
\hline 4. & 33 fó & $34,0 \%$ & $32,7 \%$ & $46,7 \%$ & $28,3 \%$ \\
\hline
\end{tabular}

Szembetűnő adat, hogy az információs technológiák oktatási felhasználásának pedagógiai, módszertani megújulást is magában foglaló negyedik válaszlehetőséget nagyjából a teljes válaszadók egyharmada jelölte meg. Jelentös eltérés mutatkozik a nagyvárosi iskolákban, illetve a vidéki kistelepüléseken dolgozó pedagógusok között. A két vizsgált adathalmazzal először F-próbát végeztünk, a vizsgált minták varianciája egymástól lényegesen nem különbözött, így kétmintás t-próbával folytattuk, s szignifikáns különbséget találtunk $(\mathrm{p}=0,001)$. Erősíti az utóbbi megállapítást az is, hogy a „,szükséges rossz kategóriája számomra” választ megjelölő négy fő mindegyike vidéki iskolában dolgozik, illetve, hogy 12,4 százalékkal többen foglaltak állást vidéken a hagyományos oktatási módszereket preferáló, s az informatikát szükséges ismeretkörként, korlátozó attitüddel közvetítő válaszlehetőség megfogalmazás mellett. A számítógéphez füződő általános viszonyulás (1. ábra), valamint az oktatási célú felhasználás szándéka közötti korreláció értéke 0,45 . Akik lelkes hívei az informatikának, azoknak 73,3 százaléka nyitott annak oktatási felhasználására is.

A vizsgálatban részt vevő pedagóguscsoport kapcsán megfogalmazható, hogy akik rendelkeznek informatikai végzettséggel, s ezzel együtt a számítógéphez füződő viszonyulásuk az átlagosnál erősebb (negyedik vagy ötödik válasz), azok közül 63 százalék az oktatásban is meghatározónak tartja az információs technológiák alkalmazását. Lényeges probléma e téren az, hogy a számítástechnikai végzettség mennyire „divat”, illetve külső elvárás a pedagógusok körében, s mekkora a belső meggyőződés, valamint a tanórai alkalmazásra is irányuló, módszertani és nemcsak számítástechnikai tudásfelhalmozás igénye. Körösné Mikis Márta a tanítóság és 
a gyermekinformatika kérdéskörére szorítkozó empirikus vizsgálatában a következő összegző megállapítást tette: „A pedagógiai felkészültség a gyermekinformatikára több tényező együttes meglétét tételezi fel. ... /a/ számítógépes tudás és pedagógiai képzettség megszerzése mellett az IKT eredményes tanításához a téma iránti elkötelezettség, pozitív beállítódás, a módszerbeli megújulást tápláló nyitottság, továbbá készség is szükséges a folytonos tanulásra, a változtatásra. Úgy tủnik, napjainkban a gyermekinformatika korai, intenzívebb tempójú elterjedését az eszközhiánnyal küzdés mellett leginkább a pedagógusok körében erőteljesen érzékelhető elzárkózás akadályozza. Ennek következménye, hogy a következő iskolafokozatokhoz képest jelentős lépéshátrányban van a kisiskolás korosztály digitális írástanításának helyzete." (Körösné, 2006.)

\section{Pedagógusok véleménye az informatikaoktatásról}

Az Európai Unió tagállamaiban eltérő módon kezelik az informatika oktatásának kérdését abban a tekintetben, hogy önálló tantárgyként, vagy más tantárgyakba integrálva közvetítik-e az informatikai tudást. Finnország gyakorlatában például az első öt évfolyamban integrált módon, hatodikban heti egy, 7-9. évfolyamokon pedig heti két óra önálló informatika tárgy is megjelenik a rendszerben. A németországi informatikaoktatásban az első négy évfolyamban integráltan, 5. és 10 . évfolyamokon az integrált felhasználás mellett heti egy szakórán zajlik az oktatás.

Felmérésünkben információkat gyüjtöttünk arról, hogy a válaszoló gyakorló pedagógusok az IKT közvetítését hagyományos tantárgyi formában, vagy integrált módon tartják elképzelhetőnek. A véleményüknek legjobban megfelelö egy lehetöséget kellett kiválasztaniuk.

A kérdés így hangzott: Ha tanit/tanitana (közvetitene) informatikai ismereteket, akkor melyik formában tudja/tudná azt elképzelni?

1. Csak külön számítástechnika/informatika órán.

2. Számítástechnika/informatika óra mellett a saját, illetve más tárgyak keretében is együttesen.

3. Csak délutáni foglalkozásokon, szakkörön, fakultáción.

4. Hasonlóan néhány európai országhoz, nem szerveznék külön szakórát, hanem a különböző tárgyak/müveltségterületek közvetítése során más szakmai tartalmakkal együtt közvetíteném az informatikai ismereteket. (Ha a személyi és tárgyi feltételek adottak.) Szerintem így is teljesíthetőek a NAT fejlesztési feladatai. 
6. táblázat: Informatikai ismeretek lehetséges formái

\begin{tabular}{|l|c|c|c|c|c|}
\hline $\begin{array}{c}\text { válaszok } \\
\text { kategóriái }\end{array}$ & $\begin{array}{c}\text { teljes } \\
\text { minta (fó) }\end{array}$ & $\begin{array}{c}\text { teljes minta } \\
\text { (százalék) }\end{array}$ & $\begin{array}{c}\text { tanitó szakosok } \\
\text { válaszai } \\
\text { (százalék) }\end{array}$ & $\begin{array}{c}\text { nagyvárosi } \\
\text { iskolákban } \\
\text { tanitók } \\
\text { (százalék) }\end{array}$ & $\begin{array}{c}\text { vidéki } \\
\text { iskolákban } \\
\text { tanitók } \\
\text { (százalék) }\end{array}$ \\
\hline 1. & 10 fö & $10,3 \%$ & $6,1 \%$ & $6,7 \%$ & $11,9 \%$ \\
\hline 2. & 55 fó & $56,7 \%$ & $55,1 \%$ & $56,7 \%$ & $56,7 \%$ \\
\hline 3. & 5 fö & $5,2 \%$ & $6,1 \%$ & $0,0 \%$ & $7,5 \%$ \\
\hline 4. & 27 fö & $27,8 \%$ & $32,7 \%$ & $36,6 \%$ & $23,9 \%$ \\
\hline
\end{tabular}

A válaszok összesítéséből (6. táblázat) kitünik, hogy a megkérdezett pedagógusok 15,5 százaléka (első és harmadik válasz összesen) csak külön órán, illetve szakkörön képzeli el az informatikai ismeretek közvetítését. Ök megerősítették az előző kérdésbeli állásfoglalásukat, ott is így nyilatkoztak ${ }^{2}$. A legtöbb választás a 2 . lehetőségre esett, amely egyrészt a hagyományos keretek megörzését (önálló szakóra), valamint a tárgyakba integrált további felhasználás, alkalmazás együttes megjelenése mellett érvelt. E tantárgyközi szemlélet jelenik meg, érvényesül leginkább a hazai oktatási törekvésekben is. Láthatók az eltérések a 6. táblázatban a vidéki iskolákban dolgozó pedagógusok és a nagyvárosi iskolák pedagógusainak válaszai között. Az informatikai ismereteknek csak integrált módon történő közvetítésére adott válaszok meglepően magasak, különösen a nagyvárosi iskolákban tanítók körében. Ez az angol oktatási rendszerre leginkább jellemző forma, mely igazán nagy, alapos felkészültséget vár el a pedagógusoktól.

A felmérés informatikai kérdéscsoportjának összegzéseként, a megkérdezettek válaszai alapján azt tapasztaltuk, hogy a pedagógusok jelentős része vett részt informatikai képzéseken. A pedagógusok a megszerzett ismereteiket az oktatás területén is felhasználják. Mindezeket megalapozhatta az elmúlt években zajló kedvezményes eszközvásárlás lehetősége és az ahhoz kapcsolódó kötelezettség, a sokszor kényszerként megjelenő, minimálisan ECDL vizsgát elváró képzésen való részvétel. A megkérdezettek 28 százaléka tartotta elképzelhetőnek az informatika csak integrált módon történő közvetítését, emellett több mint 50 százalékuk nyilatkozott úgy, hogy saját tárgyukban nyitottak az informatika alkalmazására. Az információs technológiák mélyebb, a különféle müveltségtartalmak közvetítésében is megjelenő felhasználása a felmérés tanulságai szerint megjelent, de ehhez informatika-pedagógiai (módszertani) megújulásra is szükség van. Egyetértünk Hunya Márta megállapításával a szükséges oktatáspolitikai döntésekről: „Ilyen szükséges döntés például a valóban minőségi módszertani képzések számának növelése, a mentorrendszer

\footnotetext{
${ }^{2}$ A kérdőívek sorszámmal kerültek kódolásra. A táblázatkezelő programban szűréssel megállapíthatóak voltak a megfeleltetések.
} 
kialakítása (tapasztaltabb segítő tanárok hálózatának megszervezése), a jó gyakorlat terjesztése különösen bemutató órák formájában, akár videón is, valamint az is, hogy szülessenek kézikönyvek, segédanyagok." (Hunya, 2008, 99. o.)

\section{Milyen oktatási módszereket alkalmaznak a pedagógusok?}

Az oktatással foglalkozó szakembereket erősen izgató kérdés: milyen mértékben van szükség a módszertani megújulásra? A reális válasz megtalálásának egyik útja, hogy megismerjük a „módszertani valóságot”. Ehhez kapcsolódóan a kérdőív második részében arról kérdeztük a gyakorló pedagógusokat, hogy milyen oktatási módszereket ismernek, milyen gyakran alkalmazzák azokat, és melyek azok a módszerek, amelyeket a szakterületükön meghatározónak ítélnek. Nyílt kérdéssel gyüjtöttünk információkat arról, hogy milyen oktatási módszereket alkalmaznak, a felsorolásra 12 üres helyet hagytunk. A módszerek alkalmazásának gyakoriságát (1-től, azaz a leggyakrabban alkalmazott módszertől, 12-ig) számokkal jelölhették meg a válaszadók.

A pedagógusok 541 tételt soroltak fel összesen, ezeket 48 kategóriába rendeztük. Átlagosan 5,58 módszert írtak úgy, hogy négy kérdőíven egyetlen egyet sem adtak meg. A tanító szakosok alig magasabb, 5,69-es átlagot értek el. A mintában tizenegyen írtak kilenc vagy annál több módszert, mindegyikük 20 évnél régebben van a pályán. Összesen négy megkérdezett használta ki a 12 üres helyet. Az átlag körüli hat módszert 46 pedagógus sorolt fel, közülük 29-en szintén 20 évnél régebben tanítanak. A legkevesebbet, átlagban 3,3 módszert a négy-öt éve pályán lévők írtak. Összességében kijelenthető, hogy az 5,58-as átlag nagyon alacsony, különösen akkor, ha a válaszadók 77 százaléka tíz évnél több oktatási tapasztalattal rendelkezett.

Egy, az oktatási módszerekre irányuló korábbi felmérés (Falus, 2001) másik utat választott, elöre megadott 15 oktatási módszerrel, szervezési móddal kapcsolatban kellett nyilatkozniuk a résztvevőknek. Lényegesen nehezebb útnak véljük, ha önállóan kell megfogalmazni, felsorolni a módszereket, elkészíteni a listát. Ezt mindenképp figyelembe kell venni felmérésünk eredményeinek értelmezésénél. Ha felsorolásból kell választani a pedagógusoknak, akkor a leírtak nem feltétlenül a módszertani tudást adják vissza, hiszen a felsorolás segíti, befolyásolja a felidézést. A rangsorkészítés jelzi a megkérdezettek „véleményét” a módszerek alkalmazásáról mindkét megoldás esetében. A nyílt kérdésfeltevés lehetőséget adott arra, hogy a pedagógusok megemlítsék a saját szakterületükön alkalmazott módszereket, eljárásokat is. A válaszok azonban azt jelezték, hogy ezzel nem akartak, illetve kevésbé tudtak élni a válaszadók.

A 7. táblázat a pedagógusok által említett módszereket, eljárásokat, szervezési módokat (munkaformákat) és egyéb megfogalmazásokat tartalmazza. A közös (hasonló) tartalomra utaló, de eltérő megfogalmazások, szóhasználatok ferde vonallal 
(,/') elválasztva jelennek meg a listában ${ }^{3}$. A harmadik oszlopban (csökkenő sorrendben) került feltüntetésre az adott módszerre, eljárásra stb. tett említések száma. A módszerek sorrendjét is meghatározó pedagógusok száma 69. Ök nemcsak felsorolást adtak, hanem a kérdésfeltevésnek eleget téve sorszámmal azt is jelölték, hogy melyiket alkalmazzák gyakrabban, illetve ritkábban. Az adott módszerre adott rangszámok összegének a válaszadók számával történő osztása adta meg a rangszám átlagot. Ezek a negyedik oszlopban találhatók.

7. táblázat: Pedagógusok megnyilatkozásai az alkalmazott módszerekröl

\begin{tabular}{|c|c|c|c|}
\hline 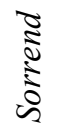 & $\begin{array}{c}\text { A pedagógusok által felsorolt módszerek, eljárások, } \\
\text { munkaformák }\end{array}$ & $\begin{array}{c}\text { Az emlitések } \\
\text { száma } \\
\text { N:93 }\end{array}$ & $\begin{array}{c}\text { Rangszám } \\
\text { átlagok } \\
\text { n:69 }\end{array}$ \\
\hline 1. & frontális munka & 73 & 2,51 \\
\hline 2. & csoportmunka & 66 & 3,51 \\
\hline 3. & önálló munka / egyéni munka / egyéni feladatok & 60 & 3,23 \\
\hline 4. & differenciálás & 52 & 2,74 \\
\hline 5. & kooperatív tanulás & 51 & 3,81 \\
\hline 6. & páros munka / tanulópárok & 46 & 4,09 \\
\hline 7. & projektmódszer / kiállítás-projekt készítése & 25 & 5,32 \\
\hline 8. & tanári magyarázat / ismeretközlés / elbeszélés & 21 & 3,67 \\
\hline 9. & kiselőadás / referátum & 13 & 6,8 \\
\hline 10. & $\begin{array}{l}\text { drámajátékok / drámapedagógia / szerepjáték / } \\
\text { szituációs gyakorlat / dramatizálás }\end{array}$ & 12 & 6,0 \\
\hline 11. & $\begin{array}{l}\text { beszélgetés / megbeszélés / beszélgető kör / párbeszéd } \\
\text { / kérdések / kérdve kifejtő módszer }\end{array}$ & 10 & 2,67 \\
\hline 12. & tanulmányi séta / kirándulás / terepgyakorlat & 9 & 6,89 \\
\hline 13. & kísérlet / vizsgálat & 9 & 5,86 \\
\hline 14. & $\begin{array}{l}\text { problémaalapú ismeretfeldolgozás / felfedeztetés, } \\
\text { kutatás }\end{array}$ & 7 & 6,86 \\
\hline 15. & könyvtári munka / könyvtári óra & 7 & 6,57 \\
\hline 16. & gyüjtőmunka / házi dolgozat & 7 & 6,8 \\
\hline 17. & bemutatás / technikák bemutatása & 6 & 2,0 \\
\hline 18. & szemléltetés / táblai applikáció & 5 & 5,0 \\
\hline
\end{tabular}

\footnotetext{
${ }^{3}$ A lista azt is tükrözi, hogy a pedagógusok körében számos, azonos tanulásszervezés és módszer külön tevékenységként él. Például: csoportmunka, kooperatív tanulás, páros munka, mozaik módszer.
} 


\begin{tabular}{|c|c|c|c|}
\hline ڤั) & $\begin{array}{c}\text { A pedagógusok által felsorolt módszerek, eljárások, } \\
\text { munkaformák }\end{array}$ & $\begin{array}{l}\text { Az emlitések } \\
\text { száma } \\
\quad N: 93\end{array}$ & $\begin{array}{l}\text { Rangszám } \\
\text { átlagok } \\
n: 69\end{array}$ \\
\hline 19. & $\begin{array}{l}\text { szövegfeldolgozás / ábra és szövegelemzés / } \\
\text { szövegértés / értő olvasás }\end{array}$ & 5 & 3,8 \\
\hline 20. & egyéni bánásmód / fejlesztés / felzárkóztatás & 5 & 4,0 \\
\hline 21. & tevékenykedtetés / tevékenységközpontú tanítás & 4 & 2,75 \\
\hline 22. & információgyüjtés / adatgyüjtés / válogatás & 4 & 3,67 \\
\hline 23. & játék / játékosság / rejtvény & 4 & 3,0 \\
\hline 24. & önellenőrzés / ellenőrzés / értékelés & 3 & 6,67 \\
\hline 25. & elemzés / mérés / forráselemzés & 3 & 5,33 \\
\hline 26. & film / oktatófilm & 3 & 8,67 \\
\hline 27. & összefüggések megláttatása / megfigyelés & 2 & 3,0 \\
\hline 28. & mozaik / csoportok közti mozaik & 2 & 6,5 \\
\hline 29. & gyakorlás & 2 & 4,0 \\
\hline 30. & verseny / vetélkedő & 2 & 11,0 \\
\hline 31. & vita & 2 & 3,5 \\
\hline 32. & igaz-hamis állítások alkotása & 2 & 4,5 \\
\hline 33. & tantárgyak összefüggéseinek megláttatása & 2 & 5,5 \\
\hline 34. & oktatóprogramok / internet a tanórán & 2 & 6,5 \\
\hline 35. & előadás & 2 & 5,0 \\
\hline 36. & motiválás & 1 & 1,0 \\
\hline 37. & modellezés & 1 & 7,0 \\
\hline 38. & rögzítés & 1 & 3,0 \\
\hline 39. & tájékozódás a térképen & 1 & 3,0 \\
\hline 40. & vázlatkészítés & 1 & 4,0 \\
\hline 41. & szótárhasználat & 1 & 5,0 \\
\hline 42. & tehetséggondozás & 1 & 5,0 \\
\hline 43. & országismeret & 1 & 5,0 \\
\hline 44. & fogalomértelmezés & 1 & 6,0 \\
\hline 45. & villámkártya & 1 & 10,0 \\
\hline 46. & szabály megfogalmazása & 1 & 10,0 \\
\hline 47. & oktatásszervezési módok & 1 & 8,0 \\
\hline 48. & gondolattérkép & 1 & - \\
\hline
\end{tabular}


A lista elején jórészt a munkaformákat, a szervezési módokat találjuk. A válaszokból kitünik, hogy a frontális munka túlsúlya nem változott. A válaszadók 77 százaléka említette, $\mathrm{s}$ a rangsort is megadók átlagosan a második, harmadik helyre tették.

A felsorolás (csökkenő) sorrendjéből feltünhet továbbá, hogy különféle tanulásszervezési módok domináns módszerei egymást követik a listában, a rangszám átlagaikból pedig egy igen heterogén kép bontakozik ki az alkalmazásra vonatkozóan. A csoportmunkát a válaszadók 71 százaléka szerepelteti, a sorrendet is megadók a 3-4. helyen említik. A differenciálást 60 százalék, a kooperatív oktatási módszert 55 százalék említi, s viszonylag „előkelő helyek” jutottak számukra a rangsorban. A projektmódszert 27 százalék sorolja fel, amire talán hatott, hogy később külön kérdésként is szerepelt a kérdőívben. Az alkalmazási rangsorban azonban már ritkábban alkalmazott módszerként jelent meg. Elgondolkodtató, hogy a magyarázat és az elbeszélés módszerét csak 22 százalék említi, melyet korábban igen gyakori szóbeli közlő módszerként tartottak számon. Igaz, rangsorát tekintve a 3-4. helyre került a sorrendet is megadó válaszolók körében.

A 93 főből összesen ketten emlitették (egy tanító szakos és egy matematikakémia szakos tanár), hogy felhasználtak számitógépes oktatóprogramokat, illetve az internet szolgáltatásait az órákon. Ha gondolatban összevetjük a korábban leírtakkal, akkor a vizsgált körben a meglévő számítástechnikai ismeretek, végzettség, valamint oktatási alkalmazására megmutatkozó hajlandóság a szakórákon egyáltalán nem tükröződik vissza. Ezen a területen úgy tünik, fontos feladatok várnak a tanárképző intézményekre, a továbbképzéseket szervezőkre, a közoktatási intézményekben tevékenykedő mentorokra.

\section{A projektmódszer ismertsége és alkalmazása}

A módszerekkel foglalkozó kérdőívrész a projektmódszer ismertségét és alkalmazását vizsgálta. A feltett kérdés így hangzott: Hallott-e a projektmódszerröl, ha igen, akkor alkalmazta-e? A vizsgált probléma, hogy az elmúlt évek továbbképzései milyen ,nyomot” hagytak a gyakorló pedagógusokban ezen a területen.

A 97 megkérdezett pedagógusból 94-en hallottak a projektmódszerröl, s közülük 63,9 százalék alkalmazta is. E válaszok tükrében kevésbé érthető, hogy miért csak 27 százalék említi meg az alkalmazott módszerek között.

A tapasztalatokkal rendelkezőktöl egy további nyílt kérdés a tapasztalatok értékelését várta: Ha alkalmazta a projektmódszert, kérem, irjon néhány mondatban a tapasztalatairól. Négy üres sor állt rendelkezésükre, ahol szabadon, támpontok nélkül fogalmazhatták meg gondolataikat. A válaszok többségéről elmondható, hogy néhány kivétellel nem konkrét, megvalósult projektekről számoltak be, hanem az alkalmazással kapcsolatban fogalmazták meg észrevételeiket. A válaszokat tartalmuk szerint csoportokba rendeztük. (Lásd a keretes írást.) 


\begin{tabular}{|c|c|}
\hline 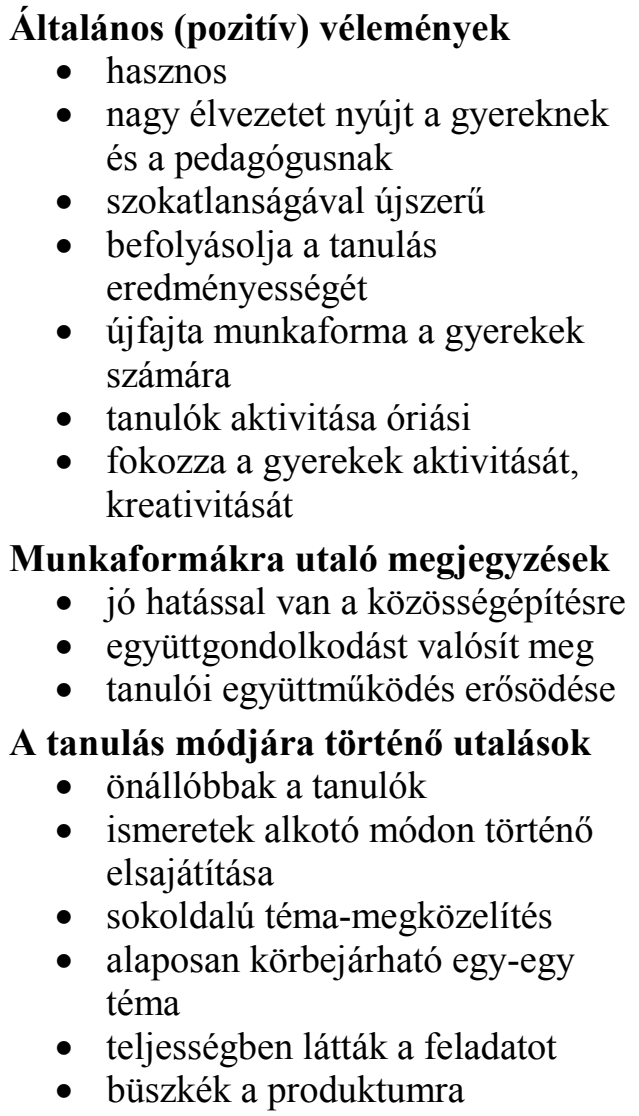 & $\begin{array}{l}\text { Nehézségek, negatívumok } \\
\text { - leterhelt tanároktól nem lehet } \\
\text { kreatív munkát elvárni } \\
\text { - } \text { időigényes } \\
\text { - több felkészülést igényel } \\
\text { a tanártól } \\
\text { - az eredmény inkább a felnőttek } \\
\text { munkáját tükrözte } \\
\text { - bizonyos tananyagnál, bizonyos } \\
\text { évfolyamon képzelhető el } \\
\text { - vannak, akik kibújnak a munka } \\
\text { - alól } \\
\text { - megelenlegi iskolai keretben nem } \\
\text { - szabad időkeretben képzelhető el } \\
\text { - a felső tagozatban valósítható } \\
\text { - meg } \\
\text { - a gyerekek állandó irányítás } \\
\text { mellett tudtak csak dolgozni } \\
\text { motiválttá kell tenni } \\
\text { a résztvevőket }\end{array}$ \\
\hline
\end{tabular}

A válaszok alapján heterogén kép bontakozik ki, melyben a pozitívumok mellett, az alkalmazás strukturális kereteinek problémái, ellentmondásai, a tanulói, illetve tanári oldal előnyös motívumai és nehézségei egyaránt jelen vannak. A véleményekben, feltehetően többen, a kooperatív módszerről fejtették ki álláspontjukat. A válaszok alapján nem szürhető ki egyértelmüen, hogy a módszert alkalmazók milyen mértékben végeztek projektjellegü tevékenységeket. Több válaszadónál is úgy tünt, hogy a pedagógiai projekt, a tanórán kiadott összetett feladat és a meglévő ismeretek begyakorlásának különféle tevékenységei összemosódnak.

Megállapítható, hogy a módszer ismertsége a korábban már említett kutatás (Falus, 2001) óta jelentősen nött. Ahogy a fentiekben már jeleztük, a régebbi felmérés 1998-1999-ben zajlott, amikor 100 pedagógust kérdeztek meg az oktatási módszerekről oly módon, hogy megadott módszerekhez kellett beírni az ismertségét és alkalmazását. Az eredményeket összehasonlítva a 8. táblázat mutatja. 
8. táblázat: A projektmódszer ismertsége és alkalmazása (1998-99; 2007-2008)

\begin{tabular}{|l|c|c|c|}
\hline \multicolumn{1}{|c|}{ A kutatások } & Hallott róla & Alkalmazta & Rangszám átlag \\
\hline 1998-1999 (100 fö) & 59 & 27 & 9,95 \\
\hline 2007-2008 (97 fö) & 94 & 62 & $5,32(\mathrm{n}: 69)$ \\
\hline
\end{tabular}

\section{A projektmódszer megismerésének forrásai}

A kérdöív utolsó kérdésköre arra irányult, hogy a pedagógusok honnan szerzik ismereteiket a projektmódszerrel kapcsolatban, melyek elsajátításának jellemző formái. Úgy véljük, hogy a válaszok elemzése alapján nemcsak a projektmódszerrel kapcsolatos ismeretgazdagításra, felkészülésre, felkészítésre lehet levonni következtetéseket, hanem tágabban, a korszerü módszerekhez kötődő módszertani kultúra gazdagításának lehetőségeiről, teendőiről is.

9. táblázat: Ismeretszerzés forrásai

\begin{tabular}{|c|c|c|c|c|c|c|c|c|}
\hline & 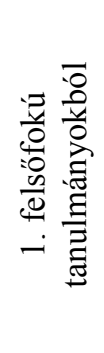 & 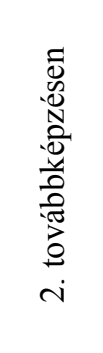 & 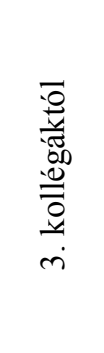 & 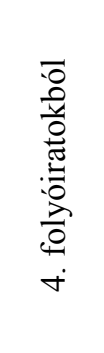 & 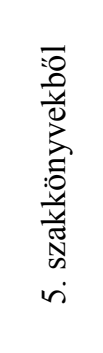 & 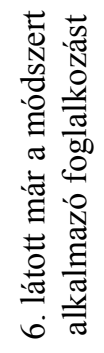 & 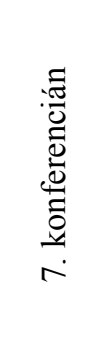 & 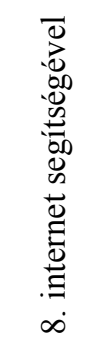 \\
\hline \multirow{2}{*}{$\begin{array}{l}\text { teljes } \\
\text { minta } \\
\text { (fó-\%) }\end{array}$} & 21 & 69 & 56 & 26 & 28 & 26 & 16 & 21 \\
\hline & $21,6 \%$ & $71,1 \%$ & $57,7 \%$ & $26,8 \%$ & $28,9 \%$ & $26,8 \%$ & $16,5 \%$ & $21,6 \%$ \\
\hline \multirow{2}{*}{$\begin{array}{l}\text { tanítók } \\
\text { esetében } \\
\text { (fó-\%) }\end{array}$} & 12 & 38 & 25 & 15 & 15 & 15 & 8 & 9 \\
\hline & $24,5 \%$ & $77,6 \%$ & $51,0 \%$ & $30,6 \%$ & $30,6 \%$ & $30,6 \%$ & $16,3 \%$ & $18,4 \%$ \\
\hline
\end{tabular}

Az ismeretszerzés forrásait a 9. táblázat összegzi. A továbbképzés, mint ismeretszerzési forrás a vizsgált körben 71 százalékos, illetve még magasabb a tanítók körében. Az adott módszert tehát elsősorban különféle továbbképzéseken sajátították el a válaszolók. Talán meglepő, hogy másodikként a kollégákat jelölték meg a pedagógusok, így egymás munkájának a megismerése, a munkaközösségekben zajló szakmai kommunikáció fontos szerepet játszik, játszhat a módszertani kultúra megújításában. (Függhet az adott szakterülettől, munkaközösségek irányítóitól, valamint az adott módszertől is stb.) Az internet, mint szakmai információs forrás ke- 
vésbé meghatározó az adatok alapján, mely a korábbiak tükrében tovább növeli a számítógépek oktatási alkalmazásának ellentmondásait. (V.ö.: A megkérdezettek 53,6 százaléka naponta, illetve hetente 2-3 alkalommal használja a számítógépet oktatást előkészítő munkája során és az oktatásban.) Úgy tünik továbbá, hogy a szakmai konferenciák hatása nem meghatározó a vizsgált témában és körben.

\section{Összegzés}

A 97 pedagógust kikérdező felmérés eredményei azt mutatták, hogy a megkérdezettek 53,6 százaléka hetente többször használ számítógépet oktatási feladatainak ellátásához. Ennek hátterében többek közt az informatikai, szakmai képzéseken történő magas részvétel húzódhat meg, így a végzettségek területén tapasztalataink jelentősen eltértek (magasabbak) a jelzett 2006-os kutatás eredményeitől (Hunya, 2008). Kiemelendő továbbá, hogy a válaszadók szintén 53,6 százaléka kihívásként, sokoldalú alkalmazási lehetőségként tekint az információs technológiákra, $\mathrm{s}$ e szemlélet jellemző a 15-20 éve pályán lévőkre is. Az informatikai eszközökhöz történő viszonyulás megalapozza, illetve kiinduló pontja az oktatásban történő felhasználási szándékoknak. Ezek az eredmények részben összhangban vannak Körösné Mikis Márta (2006) vizsgálatának néhány összegző megállapításával, ugyanakkor az általa leírt, a pedagógusok körében erőteljesen érzékelhető elzárkózást felmérésünkben nem tapasztaltuk.

Az alkalmazott oktatási módszerek vizsgálata során a nyílt kérdésfeltevés nehézséget jelentett a válaszadók számára. A válaszok a frontális munka erőteljes jelenlétét mutatják, de komoly szerepet kapnak a pedagógusok megnyilatkozásai alapján a kooperatív tanulásszervezések (csoportmunka, páros munka, kooperatív módszerek stb.) is. Az elemzések azt mutatták, hogy az informatika által nyújtott lehetőségek tanórán történő felhasználása elenyésző annak ellenére, hogy a szakmai hozzáértés és alkalmazási hajlandóság magas a vizsgált körben. Egy régebbi vizsgálat idejéhez képest (Falus, 2001) a vizsgált populációban nőtt a projektmódszert alkalmazó pedagógusok aránya, de a projektmódszer alkalmazásának tapasztalatairól tett megnyilatkozások tanulmányozása, különösen a nehézségek, negatívumok tekintetében azt jelzi, hogy még sokféle értelmezési és alkalmazási nehézség árnyalja a pedagógusok projektmódszerrel kapcsolatos képét.

Az információs technológiáknak a közoktatás egyes szakaszaiban történő oktatási alkalmazásában a gátló tényezőt már nem elsősorban az informatikai szakismeret hiánya jelenti. Úgy tủnik, hogy hiányzik egy „láncszem”, mely a számítástechnikai ismereteket pedagógiai-informatikai tudássá alakítja. E stratégiai típusú tudás kialakításában komoly feladatok várnak a pedagógusképzéssel és -továbbképzéssel foglalkozó intézményekre. Szükségesnek tartjuk a pedagógusképzés rendszerében (szakképzettségtől függetlenül) egy pedagógiai informatika kurzus bevezetését, mely nem a számítástechnikai szakmai ismeretek bővítését tüzné ki elsődleges cél- 
jául, hanem gyakorlatorientált módszertani segítséget nyújtana az információs technológiák oktatási felhasználására. A hallgatók közoktatási gyakorlatai pedig e témakörben is felkészült mentorok irányításával történhetne. A gyakorló pedagógusok számára pedig, ahogy a felmérés is mutatta, a különböző népszerü továbbképzések (akkreditált pedagógus-továbbképző tanfolyamok, pedagógus szakvizsgára felkészítő programok) biztosíthatják a módszertani, illetve az információs technológiák oktatási alkalmazásának elsajátítását. Ehhez a képzők részéről korszerü tartalmak mentén összeállított, tevékenységekre alapozó programok szükségesek.

\section{Irodalom}

Falus Iván (2001): Az oktatási módszerek kiválasztására és alkalmazására vonatkozó nézetek. In: Golnhofer Erzsébet és Nahalka István (szerk.): A pedagógusok pedagógiája. Nemzeti Tankönyvkiadó Rt., Budapest, 232-260.

Hunya Márta (2008): Országos informatikai mérés. A pedagógusok válaszainak elemzése. Új Pedagógiai Szemle, 1. sz. 69-100.

Kerber Zoltán (2007): A tanítói munka változásairól. Egy felmérés tanulságai. In: Kerber Zoltán (szerk.): Utak elmélet és gyakorlat között. A Nemzeti alaptantervtől az osztályteremig. Oktatáskutató és Fejlesztő Intézet, Budapest, 109-121.

Kőrösné Mikis Márta (2006): „Én is tudok rajzolni az egérrel...!” In: Szabó Mária (szerk.): A jövö elöszobája. Tanulmányok a közoktatás kezdöszakaszáról. OKI. Budapest.

http://www.oki.hu/oldal.php?tipus=cikk\&kod=eloszoba-En-III Letöltés ideje: 2008. 07. 22. megtekintés]

M. Nádasi Mária (2003): Projektoktatás. Gondolat Kiadói Kör, Budapest, Oktatás-módszertani kiskönyvtár. 